\title{
THE DIFFERENCE OF THE IMPACT BETWEEN FACE TO FACE COMMUNICATION COMPARED TO POLITICAL DEBATES IN CYBER SPACE
}

\author{
Hajnalka Szarvas and Tamás Mező ${ }^{1}$
}

\begin{abstract}
Singularity or ...?

The study will reveal one of the most burning questions of the field of e-governance and edemocracy, the question of the Center for Collective Intelligence of MTI, namely How can people and computers be connected so that-collectively - they act more intelligently than any person, group, or computer has ever done before? Is this possible at all? In the study it will be highlighted which are the neuropsychological effects of human to human communication compared to people and computers. Whether this latter is ever able to substitute personal face to face interactions. Are people more satisfied with electronic services where there is an artificial system in front of them? Which kind of psychological impact does it have on political behaviour and especially participation? Does it really encourage to be more active citizens? Or on the contrary it even deters? Which are the criterias of that? And finally in order to be able to answer these questions we should trace this back to the very original question of what is the real function of communication in human society?
\end{abstract}

\section{Introduction}

Probably these are the most exciting questions of e-democracy currently which is also studied by the MIT Research Labs. ${ }^{2}$

\subsection{Aim of the study}

The aim of this study is not fully answer these questions, the research method which leads us further in the understanding of these fields is rather the questioning itself. The critical inquiry as such which reveals more and more component of the topic which is necessary for highlighting the deeper roots of the problem of physical vs. online communication, debates. That way the paper is aiming to provide a more comprehensive view about the complexity of e-democracy processes, mechanisms, the deeper questions and philosophical foundations of this. Some of its aspects was already discussed in the mainstream scientific literature, but here the aim is to observe those aspects which has not been revealed yet. Of course because of the length limits it is not possible to elaborate on each interesting or important factor, but the added value of this approach can be considered the biochemical and anthropological outlining of certain communication processes, and the approach of edemocracy tools from the point of views of social economy, value sociology, value system, motivation research.

\footnotetext{
${ }^{1}$ National University of Public Service, Hungary, Budapest, Ludovika tér 2, 1083, hajnalkaszarvas@gmail.com; tomfield0@gmail.com

${ }^{2}$ http://cci.mit.edu/research_creating.html
} 


\subsection{Digitalization- Panacea for all diseases of democracy?}

According to Virgile Deville,co-founder of DemocracyOS France and Open Source Politics:

„With Blockchain technology we are now able to create a global jurisdiction that works for all of us, in cyberspace."3

Are we sure that global jurisdiction that serves everyone on the planet can be realized in cyberspace? When we see examples of political processes organized and started in cyberspace, like the Arab Spring movements, it is becoming more and more clear and common sense that these were not initiated originally by local citizens, they just became the unconscious puppets of some greater global interests.

If we compare the economic indicators of the concerned countries before the Arab Spring has started and in current days we see a sharp decline in almost each cases. As Salem, Associate Professor of Public Administration at British University in Egypt (2016) pointed out also the Egyptian economy has been hit strongly by the consequent processes of Arab Spring. ${ }^{4}$ "In the two years since the fall of Mubarak, prices of various items were up, and so was unemployment. And with the poverty rate rising from $20 \%$ to $25 \%$, businesses felt the pinch."

(...) Foreign currency reserves had dropped from $\$ 36$ billion to $\$ 26$ billion since the revolution, according to the Egyptian Center for Economic Studies. (...) The 2011 revolution prompted a downward spiral of currency weakness, capital flight and crumbling state finances. Egypt's economy took a tremendous hit during the uprisings of the Arab Spring. Egypt's GDP growth rate fell from 7.2 percent in 2008 to a paltry 1.5 percent forecast for 2012 , and as many as $40 \%$ of Egyptians were believed to be living below the poverty level." ${ }^{5}$ Needless to mention about the Libyan case where the data shows even more obvious tendencies. Professor Benjamin R. Barber, internationally renowned political theorist, author of the book Jihad vs. McWorld, founder of Interdependence Movement predicted already in 2011 about the dynamics of events in North Africa that the newly created democracies by these partly online movements are really fragile and may will not be long-lasting. As he expressed it in an interview, if the newly shaped governments will not be able to fix or maintain economic stability it is a great chance that they will fail, and being replaced by fundamentalist, islamist regimes.(Szarvas, 2011)

These facts warns us to overestimate or exaggerate the real potential of the tools of online democracy. As we can see on these examples the result that these tools, technologies can achieve is at least questionnable and at the long run not sustainable, not to mention about its manipulative potential. Namely transparency used to be mentioned as a greatest potential concerning edemocratic tools, technologies in spite of this we can see exactly the contrary, transparency is much less present in the case of these systems. These carries great opportunities for misuses which the normal users can not follow because of the lack of IT expertise, so in fact the transparency is present to a much less extent than in the traditional realm of offline politics.

\footnotetext{
${ }^{3}$ http://news.d21.me/en/communities/how-to-optimalise-modern-democracies/

${ }^{4}$ Lecture on the National University of Public Service, Hungary, 18th of November, 2016

${ }^{5} \mathrm{http}$ //www.globalsecurity.org/military/world/egypt/economy.htm
} 


\section{Limits of online political debates, discussions compared to offline communication based on the results of evolutionary psychology, genetics, neurobiology, bioinformatics}

As Lednyiczky (2007) claims on the field of bioinformatics it can be observed that the functioning
of certain cells in itself is an extremely difficult process already, not to mention about the subtle
coordination of tissues, organs and the synchronization of metabolism processes. If we were to
connect all computers in the world with some special software, neither in this case would we be
able to direct one single living organism. As he explains the bioinformatics put the emphasis on the
observation of the whole organism, not only the brain research, since each cell has its own
consciousness. The cells have their own adaptive steps. The synchronization of these extremely
complex processes means a highly complex system of communication between the cells, but not
only with each other are they connected, but also with the whole living system of human beings and
mammals due to the hippocampus of our nervous system. This functions as a special antenna which
connects us with the fundamental vibration of Earth-ionosphere, atmospheric signs and with each
other and the mammals, who's hippocampus brain region is tuned similarly to human beings. So
our thoughts and emotions are synchronized or connected through our hippocampus. ${ }^{6}$ It is also
observed that this complex communication or synchronization process is blocked or hampered
within certain circumstances like in the case of those who lives in thick wall concrete buildings or
works underground and rarely go out into natural environment. They are lack of these natural
regulatory signs, so they can be connected only partially or to a limited extent are they able to

${ }^{6}$ Rupert Sheldrake's theory about morphic resonance and morphic fields explains this phenomena further, and the existence of this connective-field gives an answer to the problem or phenomenon of space-independent coherence. He is an English biochemist born in 1942, initially dealing with plant development. In the course of his work he found results which led him to use and further develop the thoughts of French philosopher Henri Bergson. He applied these in the sphere of biology. As a result he found that 'for understanding the development of plants, their morphogenesis, genes and gene products are not enough. Morphogenesis also depends on organizing fields. The same arguments apply to the development of animals. Since the 1920s many developmental biologists have proposed that biological organization depends on fields, variously called biological fields, developmental fields, positional fields, or morphogenetic fields. All cells come from other cells, and all cells inherit fields of organization.' What he says is that there is a field which comprises certain patterns of development. Plants and animals develop according to these, which patterns can be found on a collective level of consciousness of these species, or as he called it on the level of morphogenetic fields. So through these fields all animals and plants are connected with each other, since their patterns of development come from a common resources. To put it more concretely: 'the hypothesis is that a particular form belonging to a certain group, which has already established its (collective) morphic field, will tune into that morphic field. The particular form will read the collective information through the process of morphic resonance, using it to guide its own development. This development of the particular form will then provide, again through morphic resonance, a feedback to the morphic field of that group, thus strengthening it with its own experience, resulting in new information being added (i.e. stored in the database). Sheldrake regards the morphic fields as a universal database for both organic (living) and abstract (mental) forms.' http://www.sheldrake.org/Articles\&Papers /papers/morphic/morphic_intro.html In: Hajnalka Szarvas: The Emergence of Global Consciousness and Its Impact on the System of Global Governance. (Thesis) Corvinus University of Budapest, 2011, Budapest, p.5-6. http://wiki.p2pfoundation.net/Emergence_of_Global_ Consciousness_and_its_Impact_on_the_System_of_Global_Governance_In the 1990's_Pjotr Gargyagyev Russian biophysicist and molecular biologist, $\overline{\text { Russian }}$ Academy of Sciences came basically to the same conclusion when researching DNA and human inheritance patterns with his research group in Moscow. They observed the ,junk DNA” and its functions and found that this molecule has a highly complex language. The research group came to the conclusion that the fragments of double spiral which do not take part in protein synthesis, serves the functions of communication, more exactly the so called ,hyper-coummunication”. This means a certain type of data change on the level of DNA and genetics. Gargyagyev et al. analyzed the vibratory answers of DNA and found a functioning of an own intelligent network which makes possible the hyper-communication and information flow between all being able for sensing. This can explain the phenomenon of space independent coherence, or The Einstein-Podolsky-Rosen paradox. In: Kingsley L. Dennis: Új tudatosság egy új világért, 2012 Budapest, 139-153. 
participate in this synchronization process which can lead to serious disfunctions of the nervous system, sensory and later on hormonal and other functional distunings and disharmonic states.(Lednyiczky, 2007) ${ }^{7}$

\subsection{Nature given supercoherent global communication network}

So what we see from the latest research results there exist a nature given supercoherent global communication channel between not only all human beings, but with all the living systems of the planet. The Club of Budapest's recent conference put the emphasis exactly on this supercoherent global network and supposed that if we were more tuned on these natural connective-fields our communities could function on a much higher level of being. ${ }^{8}$

When we use mobile phones, smart phones, laptops to communicate with each other, this natural communication channels, synchronization process which connects us with other human beings and the living systems of our Earth naturally, are weakened, distorted or shaded. It is just hardly revealed how electrosmog and the use of smart phones influences our above described natural „global communication networks, or channels" through the hippocampus. We do not know yet, how much of these informations we loose by using these tools instead of our ,nature given communication application." Although more and more studies and researches exposes the destructive effects of digital tools, causing different type of mental and other illnesses, concentration deficit disorder (CDD), memory disorders, sleep disorders, social phobia, depression, anxiety, low self-esteem, etc., (Kanokpornl, Peerayuthl; 2016), (Chou, Edge; 2012), (Tayyaba, 2016), (Theocharis, Lowe; 2016)

\subsection{Evolutionary limits of communication - Locality constraints of democracy (e-democracy)}

When we talk about communication, and the different technological tools, opportunities of communication we find that even if the mobile technologies makes this possible to communicate on a global scale, if we look at most of the people's call list, for the most part we find close relationships, like friends, family members, relatives. And this is true for sms-es too, most of these are orientated towards geographically close or really close dots.

\footnotetext{
${ }^{7}$ Same article, p.221-222.

${ }^{8}$ http://www.clubofbudapest.org/clubofbudapest/index.php/en/ 3-4th of December 2016, http://www.clubofbudapest. org/clubofbudapest/index.php/en/international-news The Club of Budapest Impact Program: Toward 2020
} 


\subsubsection{Tribal connection- tribal way of keeping contact ${ }^{9}$ - Global world-local connections}

The range of the mobile phones are global, and still it serves mostly the communication within smaller communities and regions. Although we live in a global world, our connections still remained local- suggests the research results of the Communication in the 21th Century- New Experiences of Connection and Community Research (2010). ${ }^{10}$ It is also not by chance that the different online communities uses the designation ,tribe”. But does it a legitimate denomination or title for them? Can we call these online communities a tribe? What are the criterias of this evolutionary way of organization? As Communication in the 21st Century (2010) shows this has another crucial factor or criteria besides group size.

\subsection{The connectivity between the users - Inner coherence, structure of communities Importance of personal physical relationships in mobile communication}

As the research highlighted the connection, communication via mobile phones, mobile technologies are only efficient if they are accompanied by previous personal encounters, so they can lean on these personal meetings, informations given on these personal occasions, and the connection can gain a confirmation through these personal physical meetings, presence. So the personal presence and connection still seems to be an indispensable part of communication, and so each kind of community. ${ }^{11}$

Therefore not all online communities can be described as a „tribe"-like organized in this sense. This explains a lot about the disfunctions and failure of those too large e-democracy projects of the European Union for example, where the users do not create a real community in this sense, there is a lack of personal relationship between the members and each kind of belonging and so the trust, the social capital in fact which lacks the most from these initiatives which would give the inner coherence of the groups. They are mostly built on misperceptions and wrong outdated mechanistic, bureaucratic theories of human relationships, just like this research results illustrates.

Mindell (2009) in his book Deep Democracy also emphasizes:

„The democratic methods, rules and laws in itself do not create a sense of community or community experience. The rules and laws can govern mechanic systems, but not people. (...) The organizations (communities) are just partly mechanic systems which needs to be changed. On the

\footnotetext{
${ }^{9}$ See more about genetically determined community size: Newman, Mark, Barabási, Albert-László, Watts, Duncan, J., The Structure and Dynamics of Networks. Princeton: Princeton University Press, 2006. ; Christakis, Nicolas, A., Fowler, James, H., Connected. The Surprising Power of Our Social Networks and How They Shape Our Lives. New York, Little-Brown, 2009 p. 174.; Takács K. 2010. Hálózati kísérletek. (Network Experiments) Közgazdasági Szemle, 57(November), 958-979. Takács K.; Janky B., and Flache, A. 2008. Collective Action and Network Change. Social Networks, 30(3): 177-189.; Janky, B. and Takács, K. 2005. Social Control, Network Structure, and Participation in Collective Action. In: Társadalmi térben. BMGE, Budapest. Tamás Freund, brain researcher, neurobiologist Director of the National Brain Research Program Hungary, prize winner researcher of the Brain Prize 2011 about higher viability of small communities: Freund suggests that in smaller communities, evolution favours patterns of behaviour that can be more cooperative, because of the capacity of our brain which is only able to follow the mutuality in smaller, transparent communities. In: Zoltán Kövecses: Creating metaphor in context, International Journal of Language and Culture, Volume 1, Issue 1, 2014, pages: $21-41$

${ }^{10}$ p. 29.

${ }^{11}$ Hungarian Youth Research (2014) also shows the same results. The common element of those organizations which were the most successful in terms of engagement were direct and strong personal connections within the group which gives a strong inner cohesion. In: Hajnalka Szarvas: Külhoni Magyar Ifjúsági Helyzetek In: Magyar identitás határon innen és túl, Új Ifjúsági Szemle online kiadvány, 2014 (szerk.) Székely Levente, p. 87-135.
} 
other hand they are living organisms as well, and their live-giving bloodstream consists of emotions, thoughts, beliefs and dreams. If we do not take into consideration this bloodstream, namely the experiences arising in each moment, then we do not pay attention the emotions and oppress what I call the dream-level (background) of everyday life, in schools, businesses and in cities in general. Cancelling the dream-level of our life finally makes us depressed. When facts are becoming more important than emotions and dreams, then we start to get bored, we do not vote, we do not go to meetings (...) The indifferent or inert participants destroys the organizations, which are going to collapse as house of cards."12

Robin Dunbar, a British anthropologist and evolutionary psychologist with his social brain theory states in fact the same than the above mentioned Tamás Freund, brain researcher, neurobiologist. According to this there is correlation between the size of the neocortex of primates and certain features of their social behaviour including the size of their group. The size of the neocortex determines the group size, so the brain can not cope and follow informations exceeding this. According to the human beings neocortex we should have live in groups of 150.(Dunbar,1992) ${ }^{13}$

The correspondence between high degree of inner coherence of groups and transparency, control of power and authentification processes will be elaborated in the second part of the study related with blockchain technology which is built basically on the same principles.

\section{The Impact of online political communication - political communication in social media on public discourse and political participation}

If we interpret communication as some kind of participation then a very important decision is, whether I participate in the nature given communication flow and connection with other human beings and all living systems that way being able to resonate all of their needs and sustaining longterm harmony or I choose to be present in the different virtual groups, online realities with weightless and responsibility-free clicking activism as a citizen? Of course that is maybe a too sharp approach of the question, and these are not absolutely exclusive categories.

According to Aczél (2014) ${ }^{14}$ one of the characteristics of $\mathrm{Z}$ generation is the almost exaggerated hunger for attention, which can even reach the level of narcissism, as it is called now ,attention economy" where the most wanted currency or goods is the attention.

So a basic difference between the previous content provider services is that while earlier these used to be a professional, paid jobs, now in the network media logic content providing is free produced by the users and almost the only and most important aspect of it is the maximalization of attention. (Merkovity)

It is also important to note that the use of social media does not provide in fact greater freedom or space for political debates. In spite of the seemingly lack of control, this works as a directed force field. As Imre and Owen (2014) formulated before the users of technology could start the radical change of politics, the technology itself ensures that the individuals become part of the already existing framework of power relationships, status quo.

\footnotetext{
12 p. 23.

${ }^{13}$ Communication in the 21th Century - New Experiences of Connection and Community 2010 Kristóf Nyíri, Mobile World Research, Magyar Telekom Nyrt. p.81.

${ }^{14}$ 2014. szeptember 26. Kutatók Éjszakája (Night of the Researchers), Corvinus University of Budapest
} 
A recent research Bene (2017) also shows that the social media is dominated by the political communication of a narrow minority. It also proved that most of the higher education students only consumes the political news, the proportion of content producers is less than $30 \%$.

\section{Information technology (IT) in human to community communication and e- governance}

\subsection{What is community and communication?}

In the main stream liberal journalism the word community is simply used for a collection of people regardless any internal cohesion in the group or mass. In a sociological sense the liberal definition is for a mass or undefined group of people.

In contrast, we are using the word community for a group of people living together, having common basis of life, work, culture, religion and having many strong cohesion forces inside, like families, relatives, friends, teams, business partnerships and so on. A community may be a small village if they rely on themselves in most of their life, and have strong internal relations.

And we use the word communication as an activity that makes them a community. Communication may use some means for that like speech, meta-communication, common activities, common pray, good will, self-abnegation, sacrifice for the existence of a community, a friendship, a family, a team and so on. Every single action holds a message towards the members that you want your community to live. Also the community involves the members in its life, it makes the member believe that he or she is needed, necessary for the community, and has an authenticated mission in the community. Communication not just makes people cooperate, but it creates community. (Vass, 2005), (Pentland, 2012)

\subsection{What motivates a member of a community to get involved in a community work?}

Motivation is in close relationship with needs, necessities and pressure on one hand, success, pleasure, reward, attention on the other. If these factors (and more) are present in the game then faith, trust, loyalty etc. may emerge, and people will be more inspired to cooperate.

The relationship between a community and a member is very similar to that of a marriage, a friendship, a business partnership or a soccer team. On one hand, there are strict requirements from each other, on the other hand, the members will be proud on their membership, the common success will be their personal success, too. We may talk about common success economy (Vass, 2005b), where investment is every act for the community, and the return is the common and personal success and pride. The situation is the same if we consider attention (Attention Economy, Beck, 2002). Of course, a successful community is dedicated for material profits, too.

Another aspect must be noted. This is personal ambitions that may be moderate or immoderate, may admit the primacy of the community or may grind his/her own axe. Such an eagerness may also lead to certain forms of cooperation. Every community needs to control (help and limit) these personal ambitions. 


\subsection{What motivates a human to communicate via IT means?}

This question is complex and cannot be answered in a short paragraph. We need to consider it as a economical issue. If using an IT tool is more pleasure or less effort or has more return than organizing a workshop then people will use it. Commercial "social media" applications combine factors that make them more widely used. Everybody is curious of their friends, they are also receiving many "likes" no matter what they post, also enjoy interesting posts, ads and ideas. Many sources of pleasure in one web application.

Also the users do not need to travel or pay to talk with their friends. A very little effort needs to be made to receive all these pleasures. However, all their opinions are widely shared, read, praised with dozens of "likes" and also argued, which is a very intensive form of attention regardless if criticised or supported.

People also use IT means when the return is more than not using them. Computation, data handling (fast search in big sets), security and many other uses make IT means worth it.

When the question emerges about e-gov (electronic governance or government) applications, we need to consider both the motivations for cooperating in a community and motivations to use IT means of cooperation. Both of them can be considered as non-material economic issues. So we can answer the following question, too: "Why people do not use our e-gov application?" Possibly, it simply does not worth it. Effort, bad feedbacks, lack of social return, lack of potential, lack of pleasures, lack of attention makes these initiatives fail. Also, in a small village, a regular meeting gives more and needs less effort than using an IT tool.

Designers of such tools should also consider the most widely used applications, too. If the logic of using your tool is very special (e.g. because an official procedure is mapped on it) then a village member who is used to Facebook will not learn it. It is simply too much effort. Or if there is no feedback on their vote or idea then they will not use it because they feel no attention to them.

An e-gov application designer also needs to consider that the giant "social media" applications are disinterested in rebuilding communities. Increasing number of studies and researches has revealed how social media changes the social behaviour of individuals, causing different type of disorders, mental illnesses, depression, etc, which makes it difficult for the users to socialize in their natural communities. Several research findings pointed out the negative consequences of the excessive use of social media for real community functioning and participation. (Hormes, 2016) ${ }^{15}$

These "social" media tools also operate as information pumps. They suck information of every people and sell them to commercial markets for business intelligence inputs. On the other side, they receive ideologies, advertisements and other (mis)leading information from their business customers (corporations, secret agencies and political parties) and pump them to the wide public. So

\footnotetext{
${ }^{15}$ As Hormes (2016) exposes "Excessive use of social networking sites (SNS) has recently been conceptualized as a behavioral addiction (i.e., "disordered SNS use") using key criteria for the diagnosis of substance dependence and shown to be associated with a variety of impairments in psychosocial functioning." Her research has proven the correlation, as she summarizes the results: „Respondents meeting previously established criteria for "disordered SNS use" were significantly more likely to use alcohol to cope with negative affect and to conform to perceived social norms, reported significantly more conflicting (i.e., simultaneous positive and negative) attitudes towards alcohol, and had experienced significantly more, and more frequent adverse consequences from drinking in their inter- and intrapersonal, physical, and social functioning, compared to individuals without problems related to SNS use."
} 
the e-gov application designer must compete with these giants and continuously make the worthiness of their tool over that of the competitors.

\subsection{What are the differences and similarities between human talk and IT communication means?}

Internet-based IT communication cannot substitute human speech but it gives numerous extra features and limitations compared to human speech:

- $\quad$ very wide accessibility: all over the world with extreme reach ratio (except for the poorest),

- frequency of replies, immediacy (answers come almost immediately, no need to post a letter, prepare a TV program or newspaper etc.),

- $\quad$ ease of use for single person without much effort to travel or organize travels,

- $\quad$ no professional control: little censorship; but likelihood of hoax-es, misleading or fake news

- $\quad$ permanence plus editability: ease of group editing a saved document or add reply to posts in social media

- $\quad$ privacy or publicity: optional if a private and strong-encrypted conversation is needed; or a high publicity blog

- $\quad$ a completely different meta-communication: IT uses analytics to discover internal and statistic correlations

- $\quad$ no common mind, only information exchange. People are often much more creative in a real workshop than in a virtual meeting

\subsection{Exposure to manipulation by power centres}

In the western democracies, manipulation is a built in element in the election systems. Both the electors and the results are subject to a heavy manipulation activity. Possibly, only very serious differences between parties are not worth manipulate.

One can say that the more IT the more manipulation can be hidden from the public. However the more IT the more data is stored hence more evidence can be collected.

In real, manipulation is a matter of public control not technology. In the case of a small, local community with its many internal coherences, the control can be more direct and fast. (Note: Localities where communities have atomized to a mass of rivals have faced with crime and juvenile delinquency which was not present before to such an extent due to control of community presence. (Bellair,1997) In the natural world we can see parallels. Lack of cooperation and increased stress and rivalry happens with trees that live far away from their large backwoods) (Wohlleben,2015)

So the best location for an e-gov system may be the locality or a community. A hierarchical structure of e-gov systems may be public controllable, too, if all logic and indicators are open and reproducible, and the hierarchy is a spatial structure, based on little localities where possibly 
everyone knows everyone (village, sub-district, <150 cooperating people according to Dunbar (Dunbar,1992) - that can organize 3-10 times more). This size can produce a good source of public data because of the good public control. Then higher (county, country) levels can be built, and their results can be double-checked against the public local data.

The best system of manipulation by the power centres is where every power branch is ruled by the power centres. Even elections are just the means of legitimation of the central power who practice their power through their parties. Contrary, the best public-controlled structure is a very strong locality who delegate their best members to a higher level local council, who also delegates their best to the parliament. This would be the least exposed to manipulation due to the strongest public control at each level. In some countries, such a hierarchy ends in a parliament house. The power centres put their parties into one house, the delegates of the nation sit in another house.

IT administration of political attitudes should also be based on small localities and organized hierarchically, and controlled at each level. The other key issue on IT systems is the publicity of all the logical rules and indicators so that every logic operations and analytic results to be reproducible.

\subsection{What extra information may help local and central government when utilizing IT means?}

IT communication is a pre-compiled form of communication. The questions and questionnaires must be well-designed, but they are very heavily subject to manipulation. However, the analysis of answers can discover much more than the answers are about. If one answers many questions then there are statistical contexts, internal relationships that say much more than the answer. You can make groups (clusters) of people along these patterns. Also, every single attitude of a person says much about that person. That is why social media systems are considered as gold-mines where the users' attitudes and opinions are the product. Billions of them make a very high-resolution market picture, from which new markets, possible threats and potentials, political and economical market gaps and trends can be uncovered. Every search is an attitude, too. This kind of analytical data sources are named data mines, and sold to corporations, political parties, secret agencies. Not the central power centres but the public groups become transparent. However, analytic tools (Kimball, Ross,2002) and data mines (Zaki, Meira, 2014) can be utilized by governments, too. And not only political preferences but yes, political will can be discovered. If a government knew what the people prefer they could better rank their strategies and programs. Also they knew what to give to the country what to the city and what to any groups of people. A better civil service, a better polity, better laws and better distribution could be achieved. This is only a matter of political will.

\subsection{What are the basic IT means of community communication and information processing and sharing the results?}

Wikies, discussion boards

Public journals, blogs, forums
Real topics, plans can be defined and discussed

Local public journalism, which really differs from power journalism

Voting sheets, questionnaires, Primary data acquisition means. surveys, polling 
Chat, voice conference, video Live speech. (permanent or not, private or public) conference

Community open budget

Project planning and organizing

Local market and small ads system Integrated local administration Analytic (intelligence) system
Every member vote with a part of their tax on local projects.

Local projects planned by professionals, executed by local companies, monitored publicly

You must give a good place to community members to sell and buy new and used goods

All public, official and monetary tasks administered here, publicated automatically, according to open rules

Statistical and OLAP analysis to discover groups of attitudes, correlations, common will. It can analyse all the data from all the above systems.

\subsubsection{Future technologies}

In this paragraph, only Blockchain is mentioned as an example. It is a good example for an IT structure that is an electronic implementation of a community feature. In ancient and traditional communities, every sacral events (e.g. the celebration of the Eucharist and the sacraments, christening, wedding, burial) have been evidenced by a large number of witnesses (e.g. a whole village). Also many of them have received remembrance or souvenir, too, that helped memorize the event. Also documents have been created that recorded the exact activities. The trust vital to run a monetary system is also based on numerous witnesses who can sell and by using that money. This evidencing feature of many witnesses is the essence of this distributed future IT technology. It offers a very high trustworthiness, reliableness and speed due to the built-in numerous miner ("witness") nodes. If one node or transaction is manipulated then hundreds will cry thief.

This technology is currently used for distributed authentication, authenticated document database (contracts, warrants, ID cards etc.) and electronic monetary substitute (Bitcoin, scriptural money). The latter usage is currently unregulated thus used to create hundreds of stock exchange balloons, but in the future, it will be also used as electronic book for community markets.

\section{Conclusion}

As a concluding remark we can state that, observing the Arab Spring and other partly or fully online organized protest movements and their outcome at the longrun, they will not be able to fix the deficiencies of "offline" or traditional politics. The realm of online politics or cyber-participation do not give an answer for the lack of transparency of traditional political decision-making, more over the lack of transparency and the potential of manipulations can be discovered to a much greater extent in e-democracy softwares and processes for an average citizen because of the lack of expertise. When the power logic behind is the same then digitalization of the process will not change anything at all. As Mánnel (2016) put it "We digitalize the wrong process the same way."16

\footnotetext{
${ }^{16}$ ceeeGov|Days2016: Central and Eastern European e|Dem and e|Gov Days 2016, Budapest, May 12-13, 2016
} 
Furthermore the research results of bioinformatics and evolutionary psychology also proves that the communication between the living systems and human beings is a much more complex and multilevel process of synchronization or attunement, co-ordination, than we would ever thought and this serves with an enormous information plus which is highly limited if not lost absolutely when this takes place in the cyberspace. The results of evolutionary psychology also explains why too large communities do not really function which can be an explanation of the failure of EU-large edemocracy initiatives. The trust of human beings is always bound to a certain locality. Researches about mobile and cyber-communication ways also revealed that these are only successful if they are associated with regular physical presence, meetings too. Kaldor, one of the most well-known researcher of global civil society movements also suggests that psysical presence still has the decisive power when it is about bringing real political changes and overcoming fears at collective levels.

What can make e-democracy tools, DMSs (Decision Making Softwares) more successful is paying greater attention to motivation and value-system researches, and developing the tools, mobilizing people according to their main goals, what really makes citizens move at the local level. The study also suggests that although blockchain technology in itself will not solve everything, still the logic behind its functioning is very much corresponding with ancient community regulations or rules, therefore it is a promising direction, just like data mines utilized by goverments could serve public interests.

There are of course countless other important questions which may arise concerning these issues, which could be a topic of another study in the future.

\section{References}

[1] BELLAIR, P. E.: Social Interaction and Community Crime: Examining - The Importance of Neighbor Networks Criminology Vol (35), Issue 4, 1997, p. 677-704.

[2] BENE, M.: Egymásra hangolva. A Facebook információforrássá válásának hatása az egyetemista fiatalok politikai viselkedésére In: Racionálisan Lázadó Hallgatók III. , Belvedere Meridionale, 2017, p. 13.

[3] CHOU, H.-T. G. and EDGE, N.: They Are Happier and Having Better Lives than I Am'": The Impact of Using Facebook on Perceptions of Others' Lives, Cyberpsychology, Behavior, And Social Networking, Vol 15, Number 2, 2012, p. 117-122.

[4] Communication in the 21th Century - New Experiences of Connection and Community 2010 NYÍRI, K., Mobile World Research, Magyar Telekom Nyrt.

[5] DAVENPORT, T. and BECK, J.C.: The Attention Economy - Understanding The New Currency Of Business, 2002.

[6] DUNBAR, R. I. M.: Neocortex size as a constraint on group size in primates, Journal of Human Evolution, 1992.

[7] KIMBALL, R. and ROSS, M.: The Data Warehouse Toolkit - John Wiley and Sons, Inc, 2002. 
[8] HORMES, J. M.: Under the influence of Facebook? Excess use of social networking sites and drinking motives, consequences, and attitudes in college students, Journal of Behavioral Addictions Vol (5), Issue 1, p. 122-129.

[9] IMRE, R., OWEN, S.: A közösségi média és az alanyiság: A kormányzás információtechnológiai birodalma 243-263. http://mek.oszk.hu/14700/14786/14786.pdf

[10] KANOKPORN, S., PEERAYUTH, C.: Face it, don't Facebook it: Impacts of Social Media Addiction on Mindfulness, Coping Strategies and the Consequence on Emotional Exhaustion. Stress \& Health: Journal of the International Society for the Investigation of Stress. Oct2016, Vol. 32 Issue 4, p. 427-434. 8p.

[11] LEDNYICZKY, G.: Elménk birodalma: tudat, módosult tudat In: Világokon át- barangolás a metafizika birodalmában, Pilis-Print Kiadó, 2007, p. 220.

[12] MERKOVITY, N.: A politikusok médialogikája a közösségi oldalakon: Facebook és Twitter kutatás p. 169 (p.165-192.) http://mek.oszk.hu/14700/14786/14786.pdf

[13] MINDELL, A.: Deep Democracy: Nyitott fórumok-Demokrácia minden szinten, Nyíregyháza: Pilis Print Kiadó, 2009.

[14] PENTLAND, A. S.: Leading Teams (multiple short articles); 2012, Harward Business Review https://hbr.org/2012/04/the-new-science-of-building-great-teams

[15] SZARVAS, H.: The Emergence of Global Consciousness and Its Impact on the System of Global Governance. (Thesis) Corvinus University of Budapest, 2011, Budapest, p. 28. http://wiki.p2pfoundation.net/Emergence_of_Global_Consciousness_and_its_Impact_on_the _System_of_Global_Governance

[16] TAYYABA, A.: Too much Face and not enough Books! Impact of Facebook Addiction on Academic performance. Annals of Abbasi Shaheed Hospital \& Karachi Medical \& Dental College. Sep2016, Vol. 21, Issue 3, p.193-194. 2p.

[17] THEOCHARIS, Y., LOWE, W.: Does Facebook increase political participation? Evidence from a field experiment. Information, Communication \& Society; Oct2016, Vol. 19 Issue 10, p. 1465-1486, 22p.

[17] VASS, Cs.: Hatalom, Szakralitás, Kommunikáció -- Kölcsey Int., 2005.

[18] VASS, Cs.: Bevezető Fejezetek A Társadalom-Gazdaságtanba -- Kölcsey Int., 2005.

[19] WOHLLEBEN, P.: Das geheime Leben der Baume; 2015, Ludwig Verlag

[20] ZAKI, M. J., MEIRA, W. Jr.: Data Mining and Analysis: Fundamental Concepts and Algorithms; Cambridge University Press, May 2014. 